\title{
O CENTRO DE DOCUMENTAÇÃO HISTÓRICA DA FUNDAÇ.̃̃O DE AMPARO À PESQUISA DO ESTADO DE SÃO PAULO.
}

\author{
DULCE HELENA PESSOA RAMOS \\ $e$ \\ RAQUEL GLEZER \\ Instrutoras voluntárias da Cadeira đe História da Cl- \\ vilizaçāo Antiga e Medieval da Faculdade de Fllosolia, \\ Ciências e Letras da Universidade de Sáo Paulo.
}

O Centro de Documentação Histórica da Fundação de Amparo à Pesquisa do Estado de São Paulo, fundado em 1966, corresponde à concretização do ideal de várias gerações de historiadores, que desde há muito sentiam a necessidade de um organismo especializado no arquivamente e preservação de nosso acêrvo documentário, disperso em condições precárias pelo país.

Algumas tentativas de organização nêsse sentido foram esboçadas, como a da Profa. D. Maria Regina Simões de Paula, que inspirada na Filmoteca Histórica do Pe. Bruxel no Rio Grande do Sul, tentou organizar no Departamento de História da Faculdade de Filosofia, Ciências e Letras da Universidade de São Paulo um núcleo informativo de fontes históricas .

A Fundação de Amparo à Pesquisa do Estado de São Paulo traduzindo sua alta compreensão das necessidades da pesquisa histórica no Brasil, instalou no referido Departamento o Centro de Documentação Histórica, sob responsabilidade do Prof. Eurípedes Simões de Paula .

Tem êsse núcleo exigido trabalho e abnegação de seus elementos. Dentre êles gostaríamos de deixar lavrada aqui nossa expressão de gratidão ao Prof. Aziz Ab'Saber, que no seu grande idealismo, muito contribuiu para o funcionamento e consolidação dêsse Centro.

Os ideais que inspiraram sua formação foram aquêles do Institut de Recherches et Histoire des Textes, de Paris, adaptados, naturalmente, à realidade de nossa pesquisa histórica .

Assim, tem o Centro duas funções bem distintas: a de salvaguardar o acêrvo documental histórico dos arquivos públicos e particulares, dispersos pelo Brasil, e de auxiliar tècnicamente através de suas máquinas e de uma equipe especializada, os pesquisadores interessados , 
Nada melhor, para maior entendimento das finalidades primordiais do Centro que a transcrição dos itens principais de seu regulamento provisório:

1. - reunir e catalogar documentos primários e bibliografias especializadas, de interêsse geral para estudos históricos e para o planejamento de pesquisas historiográficas;

2. - reunir catálogos de arquivos, museus e bibliotecas, atlas e mapas históricos, para facilitar a consulta documentária e amparar a programação de pesquisas;

3. - proceder à microfilmagem de documentos primários de interêsse coletivo para pesquisas históricas e sociais, tais como coleções de documentos de arquivos públicos e particulares, obras raras, coleções de jornais e revistas;

4. - colocar em mãos dos pesquisadores interessados, através de assessoramento técnico, equipamentos para microfilmagem de documentação;

5. - reunir documentos didáticos (microfilmes, reproduções, cartas históricas, fotografias e slides) de interêsse especial para o ensino da História em nível universitário.

No plano de auxílio aos pesquisadores muita coisa já tem sido feita, paralelamente ao trabalho de organização e assistência administrativa que se desenvolveu ao longo de todo o ano de 1967. Exemplo disso é o número de pessoas, que dos mais variados setores de trabalho, vem nos procurar para empréstimo das diferentes máquinas de microfilmagem, tais como Nikon, Asahi Pentax, Contarex Zeiss, Exata Varex, Exa, e outras .

Nêsse setor destaca-se o técnico do Centro, Kunio Suzuki (aluno do $4^{\circ}$ ano de História), que extende suas atividades confeccionando slides ou microfilmando documentos necessários às tarefas didáticas do corpo docente do Departamento de História .

Em 1968, o Centro tendo já resolvido as dificuldades iniciais que a formação de um núcleo especializado implica, partiu para cumprir a sua finalidade primordial, ou seja, a preservação da nossa documentação histórica. Dois planos de pesquisa então foram elaborados: o de Ana Maria de Almeida Camargo e o de Dulce Helena Pessoa Ramos-Raquel Glezer.

$O$ primeiro, referente ao elvantamento de jornais existentes no Instituto Histórico e Geográfico de São Paulo. Trata-se de um arrolamento exaustivo, para futura microfilmagem, da coleção de periódicos da Hemeroteca "Júlio de Mesquita" do próprio Instituto. Cêfca de 700 diferentes periódicos, dessa incalculável coleção de jornais e revistas do Brasil, já foram catalogados. Esta catalogação visa não só informar a respeito do que existe na Hemeroteca, mas 
também levantar todos os dados a respeito de cada um dos jornais ou revistas encontrados, a fim de completar, mais tarde, as falhas existentes nas principais histórias da imprensa.

O segundo trabalho é a microfilmagem do acêrvo documental do Museu das Bandeiras da cidade de Goiás. A primeira etapa do vasto plano de pesquisa elaborado, será a microlmagem da documentação referente ao período colonial. Essa pesquisa vem de encontro ao espírito do Centro de Documentação Histórica. Pois, se de um lado efetuaremos a microfilmagem maciça de documentos em estado precário, por outro traremos êsses documentos, concentrados em região de difícil acesso, ao alcance dos pesquisadores.

Contribuiremos assim não só para a divulgação de nossa documentação histórica, como para sua racionalização e barateamento de seu custo.

Procurando através de suas atividades realizar os ideais que nortearam sua fundação, espera o Centro de Documentação Histórica, num futuro breve, ser o grande manancial de fontees primárias, indispensável a todos os pesquisadores brasileiros. 